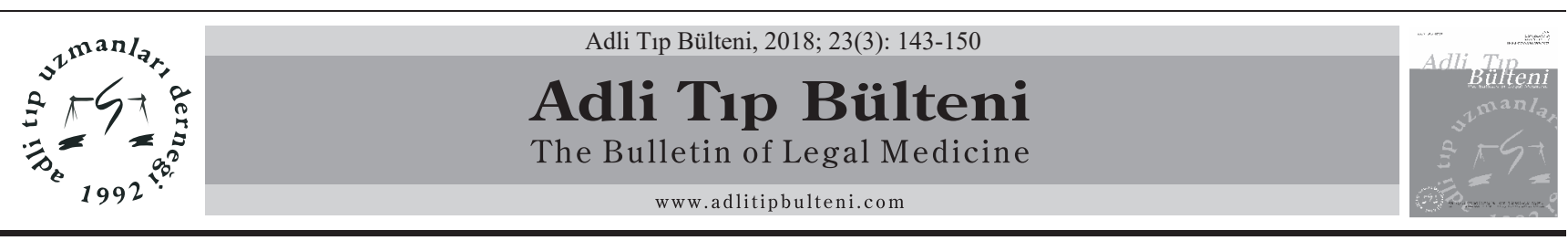

\title{
Caydırıcılığın Madde Kullanımı Açısından Üniversite Öğrencilerinde Değerlendirilmesi
}

\author{
The Evaluation of Deterrence in University Students with Regards to Substance Use
}

\author{
Burcu Türk ${ }^{1}$, Mustafa Fatih Yavuz ${ }^{2}$ \\ ${ }^{1}$ Haliç Üniversitesi, Psikoloji Bölümü, İstanbul

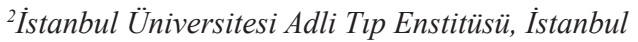

\section{Özet}

Amaç: Suçla mücadelede en önemli unsurlardan biri ceza politikalarıdır. Bu araştırmanın amacı madde kullanımı açısından ceza yaptırımlarının ne anlama geldiğini saptamaya çalışmak ve cezalandırmanın bireylerin suç işlemelerindeki etkisini, cezaların caydırıcı olup olmadığını ortaya koymaktır.

Gereç ve Yöntem: Bu araştırmanın örneklemi üniversitelerde öğrenim görmekte olan öğrencilerden oluşmaktadır. Araştırmanın anket yoluyla bilgi toplama aşamasına toplam 277 üniversite öğrencisi katılmıştır.

Bulgular: Katılımc1ların \%17,9'u esrarı, \%3,4'ü eroini, \%4,5'i kokaini, \%2,6's1 LSD'yi, \%4,5'i ecstasyi, \%3'ü bonzaiyi en az bir kez kullandıklarını bildirmişlerdir Öğrencilerin \%41,4'ünün okul idaresinin madde kullanan öğrencileri fark etme olasılığının düşük olduğunu, \%71,6'sının madde kullanımının yasal olarak suç olduğunu bildiği, \%44,2'sinin madde kullanımına verilen cezaların caydırıcı olmadığını düşündüğü görülmektedir. Madde kullanan öğrencilerin \%54,9'u, kullanmayan öğrencilerin ise \%24,1'i madde kullanımından dolayı bir kişinin yakalanma olasılığını düşük bulmaktadır. Öğrencilere anket çalışmasında madde kullanmama nedenleri sorulduğunda \%64'ünün sağlığıma zararlı olacağını düşündüğüm için yanıtı verdiği görülmüştür. Yakalanma risk algısına bağlı olarak ceza almaktan ve yakalanmaktan korktuğum için yanıtını verenlerin oranının ise toplamda $\% 9$ olduğu görülmüştür.

Sonuç: Araştırmanın sonuçlarına göre katılımcıların madde kullanımına verilen cezalar ile ilgili net bir bilgi sahibi olmadıkları ve cezai yaptırımlar konusunda özellikle kesinlik ve şiddetlilik prensiplerine olan inançlarının düşük olduğu görülmüştür.

Anahtar Kelimeler: Madde Kullanımı; Caydırıcılık; Risk Algısı; Üniversite Öğrencileri.

\section{Giriș}

Suçla mücadelede en önemli unsurlardan biri ceza politikalarıdır. Günümüzde suç ve suçlulukla etkin bir şekilde mücadele edebilmek için cezaların caydırıcı ve ıslah

Sorumlu Yazar: Dr. Öğr. Üyesi Burcu Türk

Haliç Üniversitesi, Psikoloji Bölümü, İstanbul

E-mail: turkburcu@hotmail.com

Geliş: 12.09.2018 Düzeltme: 08.10.2018 Kabul: 02.11.2018

\begin{abstract}
Objective: One of the most important components in the fight against crime is penal policies. The aim of this research is to determine the meaning of penal sanctions with regards to substance use and reveal the influence of punishment in individuals committing an offence, also whether the penalties are deterrent or not.

Materials and Methods: The sample of this research is made up of students studying in universities. 277 university students participated to the gathering information phase of this research through survey method.
\end{abstract}

Results: The participants stated in the following percentages that they used the below substances at least once; $17.9 \%$ marijuana, $3.4 \%$ heroine, $4.5 \%$ cocaine, $2.6 \%$ LSD, $4.5 \%$ ecstasy, $3 \%$ bonsai. $41.4 \%$ of the students think that the probability of school administration's noticing the students using substance is low. $71.6 \%$ know substance use is a crime legally and $44.2 \%$ think that the penal sanctions given for substance use are not deterrent. $54.9 \%$ of the students using substances and $24.1 \%$ of students not using substances think that seizure risk of a person using substances is low. When the reasons of not using substance is asked during the survey; $64 \%$ of the students stated that they believe it will be harmful for their health, while $9 \%$ declared fearing punishment and seizure depending on the risk perception of seizure.

Conclusion: Per the results of the research, it is possible to state that the participants do not have clear information about the punishments imposed for substance use and about penal sanctions, their confidence to especially accuracy and direness principles are low.

Keywords: Substance Use; Deterrence; Risk Perception; University Students. edici olması büyük önem taşır. Yakalanma ve cezaland1rılma risk algısı, suç işleme eğilimi içinde olan bireylerde caydırıcı bir etki taşımaktadır.

Aydınlanma çağı ile birlikte ortaya atılan akılcılık ve rasyonalite fikirleri temelinde yükselen ve suçu da rasyonel bir tercih olarak gören Klasik Okul düşünceleri, Orta Çağ’ın suç ve suçluya bakışındaki geri kalmış, zalim ve barbar uygulamalarına bir tepki olarak, insanı ve insan onurunu ön plana çıkaran yaklaşımının eseridir. $\mathrm{Bu}$ an- 
lamda Klasik Okul, suç ve cezaya bakış noktasında dünya çapında etkiler meydana getirmiş ve halen de etkileri devam eden güçlü bir düşünce okuludur. Bu nedenle de, ortaya koyduğu güçlü mantıksal çerçevesi günümüzün gelişmiş demokrasilerinin ceza adalet sistemlerinin de temelini teşkil etmektedir (1).

Klasik okul düşünce sistemi içinde cezaların varlığını izah eden üç temel görüş bulunmaktadır. Bu fikirlerden birincisi; suçluya hak ettiği cezayı vermek ve mağdurun öcünü almak, ikincisi; bireyi caydırarak bir daha suç işlemesini engellemek ve son olarak da topluma suçluların hak ettikleri cezaları aldıkları mesajını vererek genel anlamda suçun önlenmesidir (2).

Kuramın önde gelen temsilcilerinden Bentham, suçlulara verilecek cezaların hızlı, kesin, ciddi ve kararlılıkla uygulanması durumunda, bireylerin suç işlemelerinin engellenmesinde caydırıcı bir işlevin yerine getirildiğini ileri sürmektedir. Burada önemli olan husus, suç eylemine verilen uygun bir cezanın hem suçlu hem de potansiyel suçlu açısından bir caydırma görevi görmesidir. Diğer bir deyişle, suçluya verilen ceza, onun yeniden suç işleme olasılığını azalttığı gibi, toplumda da suç işleme eğiliminde olan bireyleri de suç işlemekten caydırmaktadır. İlkinde ceza, bireysel/öznel anlamda bir caydırıcı rolü yerine getirirken, ikincisinde ise genel önleme açısından bir fonksiyonu yerine getirmektedir (3).

1764 yılında yayınladığı "Suç ve Ceza Üzerine Bir Deneme" (An Essay on Crime and Punishment - Eserin ilk yazıldığı şekliyle orijinal adı: Dei Delitti e Delle Pene) eseriyle Beccaria, ceza adalet sistemini yeni baştan inşa edecek devrim niteliğinde fikirler ortaya atmıştır. Bu eserinde Beccaria, kanunların kaynağı, nasıl yapılmaları ve nasıl yorumlanmaları gerektiğine, cezaların neden bir ihtiyaç olduğuna ve cezaların sahip olmaları gereken niteliklerine değinmiştir (1).

Beccaria'ya göre cezalar, mağdur olan veya zarar gören kişinin itibar veya saygı değerliğine, veya mağdurun çektiği 1stıraba göre değil, topluma verilen zarar esas al1narak verilmelidir (2).

Kriminologlar, cezalandırmanın veya cezaların suç oranları üzerindeki caydırıcı etkisini; spesifik/bireysel ve genel caydırıcı olmak üzere iki genel başlık altında ele almaktadırlar. Özel caydırıcı, suç işlemiş bir bireyin cezalandırılmasının söz konusu bireyde yeniden suç işleme cesaretini göstermemesini tanımlamaktadır. Genel caydırıcı ise, suç işleyen bireye verilen ceza ile toplumun genelinin bu cezadan etkilenerek suç işlemekten caymalarını açıklamaktadır (4).

Cezaların caydırıcı olabilmeleri için Beccaria (2003) üç temel prensip ortaya koymaktadır. Bu prensipler önem sırasına göre: [1] kesinlik (certainty), [2] hızlılık (celerity/swiftness) ve [3] şiddetliliktir (severity) (5).

Kesinlik, diğer ilkeler arasında en önemli caydırıcılık faktörüdür. Kesinlik ve suç arasında ters bir ilişki mevcuttur. Cezanın kesinliği arttıkça suç işleme oranı azalmaktadır. Cezaların er ya da geç uygulanacağı kanaati ne kadar yayılırsa, insanlar cezadan kaçış olmadığını bileceklerinden dolayı suç işlemeden önce durup iyice düşüneceklerdir. Cezadan kaçış ihtimalinin çok zayıf olması, hatta pek de mümkün görülmemesi asıl caydırıcılığı sağlayacak faktördür (1).

Cezaların suç teşkil eden eylemlerin hemen peşi sıra ve hızla gelmesi, suç ve ceza arasındaki bağlantının kopmaması açısından önemlidir. Bu nedenle, yakalama ve gözaltına alma gibi polisiye tedbirler ile adalet mekanizmasının vakit kaybetmeden yargılamayı yaparak en kısa sürede kararını vererek suçluyu gerekli cezaya çarptırması suçluların caydırılabilmesi için kritik önemi haizdir. Bu noktada Beccaria (2003), "bir suçun işlenmesini takiben bir ceza ne kadar çabuk verilebilirse o ölçüde adil ve amacına ulaşmış olur" demektedir $(1,5)$.

Cezaların şiddetli olması da caydırıcılık için önemli bir diğer husustur. Ancak Beccaria'ya göre bu şiddetlilik, cezaların suçlarla orantılı bir şiddette olmasını ifade eder. Her ne kadar suçun kontrol altına alınması, işlenme sıklığının azaltılması ve mümkün olduğu kadar önlenmeye çalışılması ideal bir hedef olarak önümüzde dursa bile suçun tamamen önlenemeyeceği de kesin bir gerçektir. Dolayısıyla, suçluları ve potansiyel suçluları caydırabilmek için cezaların işlenen suçla orantılı olmaları gerekmektedir (5).

Suçla orantısız cezalar, suçlarla cezalar arasındaki bağlantıyı kopardığı için caydırıcılık gerçekleşmez. Cezanın suça göre az olması durumunda suçun 'maliyeti' azalır ve dolayısıyla da suç işlemek daha rasyonel bir seçenek haline gelir. Cezaların çok yüksek olması durumunda da, hem bireyde hem de toplumda suçlunun haksızlığa uğradığı fikrinin yerleşmesine neden olur ve bu durumda da suçla ceza arasındaki bağlantı kopar ve dikkatler başka bir yöne kayar. Dolayısıyla, bu senaryoda da caydırıcılık gerçekleşmez (1). Sherman (1993) kişinin aldığı cezayı haksız bulması durumunda kişide direnç oluşacağını ve dolayısıyla da suçtan caymak yerine yeniden suç işleme yolunda daha da bileneceğini ifade etmektedir (6).

Madde kullanımı açısından caydırıcılıkla ilgili literatürde çok fazla araştırma olmadığı dikkati çekmektedir.

Risk algısının madde kullanımı ile ilgili davranışları şekillendirme konusunda kritik bir öneme sahip olduğu gösterilmiştir (7). Bazı çalışmalar algılanan riskin madde kullanımı başlangıcında ya da madde kullanımından kaçınmada $(7,8)$ kritik olduğuna işaret ederken, bazı ça- 
lışmalar da algılanan riskin aktif madde kullanıcılarının davranışlarına da etki ettiğine işaret eder $(9,10)$.

Kelly ve ark.nın (2014) yaptığı bir araştırmaya göre kullanıcıların çoğu $(\% 59,1)$ metamfetamini bir ya da iki kez kullanmanın kullanıcı için risk teşkil etmediğini düşünmektedir, yalnızca \%11,2'si bir ya da iki kez kullanımda en azından orta derecede risk oluşturacağını belirtmiştir. Bu düşünceler metamfetaminin düzenli kullanımı söz konusu olduğunda değişmektedir. Metamfetaminin haftada bir ya da iki kez kullanımının oluşturacağı riskler sorulduğunda katılımcıların yalnızca \%19,8'i hiçbir risk olmadığını belirtmiş, çoğunluğu ise $(\% 56,7)$ düzenli kullanımda en azından orta derecede risk taşıdığını beyan etmiştir (11).

Özcan ve ark. (2011) 9, 10, 11 ve 12. sinıflar arasında 500 öğrenci ile yaptığı araştırmada öğrencilerin \%37,1'i okul idaresi tarafindan uyuşturucu kullanımının fark edilmesi ve şikâyet edilmesi ihtimalini yüksek bir olasılık olarak değerlendirmiştir. Okul idaresinin vereceği cezayı da öğrencilerin \%21,4'ü çok ağır bir ceza, \%46,1'i se ağır bir ceza olarak öngörmektedir. Uyuşturucu kullanımı yüzünden hapis cezası alma ihtimalleri sorulduğunda ankete katılanların bu soruya vermiş oldukları ortalama değer 4,8/10'dir. "Sizce bu tür bir suçu işleyen suçlunun adalet önüne çıkarılması ne kadar zaman alır?" sorusu ile öğrencilerin bu tür bir suçu işlemeleri durumunda kendilerini ne kadar sürede adalet önünde bulacaklarını tahmin ettikleri sorulmuştur. Öğrencilerin \% 7,6's “çok kısa bir süre”, $\% 29,2$ 'si kısa bir süre, \%30,9'u uzun sayılamayacak bir süre, $\% 20$ 'si uzun bir süre ve $\% 12,3$ 'ü çok uzun bir süre şeklinde cevap vermişlerdir (12).

Dünya Sağlık Örgütü'ne göre uyuşturucu madde tanımı: "Bitkisel kökenli ya da sentetik olup, merkezi sinir sistemini etkileyerek fiziksel ve/veya ruhsal bağımlılık hallerine yol açan ve tutku yaratan bütün maddeler uyuşturucu madde sayılır” şeklindedir. Dünya Sağlık Örgütü'nün tanımlarına göre ayrıca "narkotik" kelimesi yaygın olarak opiyat ve opioidleri, "drog" kelimesi ise psikoaktif maddeleri tanımlamak için kullanılmaktadır (13).

Madde kullanımı günümüzün en önemli toplumsal sorunlarından biri olup madde kullanım yaygınlığının giderek arttığı görülmektedir (14). Toplumdan topluma değişiklik göstermekle birlikte alkol ve diğer maddelere başlama yaşı çoğunlukla orta veya geç ergenlik dönemleridir. Dünyada ve Türkiye'de gençlerin madde kullanmasıyla ilgili araştırmalar daha çok ilköğretim ve lise dönemini kapsamaktadır. Bununla birlikte üniversite döneminde de madde kullanımı halk sağlığı ve öğrenim yaşamı açısından önemli bir sorundur (15).

Bireyler neden madde kullanmaktadır neden bağım1 olmaktadır gibi sorulara alternatif olarak birçok cevap ortaya çıkmaktadır. Kişileri bağımlı olmaya iten dört ana faktör bulunmaktadır. İlki bireylerin madde kullanımı sonucu kendilerini iyi hissetme amaçlı haz duyusunun etkisiyle madde kullandıkları ortaya çıkmıştır. Eroin bağımlılarının memnuniyet duygusu ile kokain bağımlılarının kendine aşırı güven duyma hissi ile madde kullandıkları bilinmektedir. İkinci olarak, kişinin yaşadığı psikolojik sorunlarla başa çıkma yolu olarak maddeyi tercih etmesi yer almaktadır. Sosyal kaygı bozukluğu olan kişilerin madde kullanarak kaygısını azaltma eğilimi bulunmaktadır. Üçüncü olarak ise, kimi insanlar eğlenmek ve bilişsel açıdan daha aktif ve yaratıcı olmak için madde kullanmaktadır. Bir diğer sebep de madde kullanmaya duyulan meraktır. Ülkemizde yükseköğrenim kurumları bünyesinde bağımlılıkla mücadele merkezlerinde bağımlılık konusu uzmanlar tarafindan ele alınmaktadır. Bu konuda çalışma yapan üniversitelerden, Avrasya Üniversitesi Bağımlıkla Mücadele Merkezi, bireyleri bağımlılığa iten sebepleri, kişinin hayatındaki sorunlarla başa çıkamaması ve kötü arkadaş çevresinin etkisi olarak göstermiştir. Özellikle madde kullanım yaş aralığının \%43'lük kısmını oluşturan 16-20 yaş grubunda görüldüğünü de belirtmiştir (16).

Bu çalışmada madde kullanımı açısından ceza yaptırımlarının ne anlama geldiğini saptamaya çalışmak ve cezalandırmanın bireyler üzerindeki etkisini, cezaların caydırıcı olup olmadığını tartışarak, ülkemizde bu alanda yapılabilecek araştırmalara bir katkı yapmayı amaçlamaktadır.

\section{Gereç ve Yöntem}

İstanbul Üniversitesi Adli Tıp Enstitüsü’nün 12.06.2015 tarihli yazısında bu araştırmanın yapılabilmesi için onay verilmiştir. Araştırma tanımlayıcı tipte planlanmış ve 1 Ocak 2016 ile 1 Haziran 2016 tarihleri arasında yürütülmüştür.

Araştırmanın örneklemini, üniversitede öğrenim gören rastgele seçilen bölüm ve sinfflardaki 277 öğrenci oluşturmaktadır. Örneklemi oluşturan öğrencilerin belirlenmesinde gönüllülük ilkesi esas alınmış ve çalışmaya katılmak istemeyen ve formları eksik dolduran öğrenciler araştırma dışında tutulmuştur.

Araştırmanın verileri, araştırmacılar tarafından literatür taranarak oluşturulan anket formu kullanılarak topland. Oluşturulan bu formda ilk olarak üniversite öğrencilerini tanımlayıcı bilgilere (yaş, cinsiyet, medeni durum) yer verilmiş, ikinci olarak madde kullanımına ilişkin sorulara yer verilmiş ve üçüncü aşamada ise madde kullanımının yasal süreçleri ile ilgili bilgi ve yeterliklerine yönelik sorulara yer verilmiştir. Tüm veriler gönüllülük esasına göre, anonim olarak, kimlik bilgileri alınmadan etik kurallar çerçevesinde toplanmıştır. 
Araştırma verilerinin istatistiksel çözümlemeleri için SPSS for Windows 22 (Statistical Package for Social Sciences) programı kullanılmıştır. Verilerin analizinde ise tanımlayıcı istatistiksel değerlerin hesaplanmasından yararlanılmıştır.

\section{Bulgular}

$\mathrm{Bu}$ anket çalışmasına farklı üniversitelerde eğitimlerine devam etmekte olan toplam 277 üniversite öğrencisi katılmıştır.

Araştırmaya katılanların \%41,5'i erkek; \%58,5'i kadındır. Katılımcıların yaş ortalaması $21,27 \pm 2,11$ 'dir. $\% 98,2$ 'si bekar, $\% 1,8$ 'i ise evlidir.

Öğrencilerin ilk sigara kullanım yaşının $16 \pm 3$ yıl olduğu, şu anda aktif olarak \%67,5'inin sigara içmediği, \%32,5'i sigara içtiği görülmüştür.

Öğrencilerin ilk nargile kullanım yaşının $16 \pm 2$ yıl olduğu, şu anda aktif olarak \%54,5'inin nargile içmediği, $\% 45,5$ 'i nargile içtiği görülmüştür.

Uyuşturucu / uyarıcı maddelerin katılımcılar tarafindan daha önce hiç kullanılıp kullanılmadığı, eğer kullanıldıysa kaç defa kullanıldığına dair sorulan sorulara verilen yanıtlar şöyledir: Katılımcıların \%82,1'i esrarı, \%96,6's1 eroini, \%95,5'i kokaini, \%97,4’ü LSD’yi, \%95,5'i ecstasyi, \%97,0’’i bonzaiyi hiç kullanmadıklarını bildirmişlerdir (Tablo1).

Tablo 1. Öğrencilerin madde kullanımı.

\begin{tabular}{|l|c|c|c|c|}
\hline & Sıklıkla & Ara sıra & $\mathbf{1 - 2}$ kez & $\begin{array}{c}\text { Hiçbir } \\
\text { zaman }\end{array}$ \\
\hline Esrar & $\% 1,9$ & $\% 4,5$ & $\% 11,6$ & $\% 82,1$ \\
\hline Eroin & $\% 0,0$ & $\% 0,7$ & $\% 2,6$ & $\% 96,6$ \\
\hline Kokain & $\% 0,0$ & $\% 1,5$ & $\% 3,0$ & $\% 95,5$ \\
\hline LSD & $\% 0,0$ & $\% 1,9$ & $\% 2,6$ & $\% 97,4$ \\
\hline Ecstasy & $\% 0,0$ & $\% 0,4$ & $\% 2,2$ & $\% 95,5$ \\
\hline Bonzai & $\% 0,0$ & $\% 1,1$ & $\% 1,9$ & $\% 97,0$ \\
\hline
\end{tabular}

Öğrencilerin ilk kez madde kullanım yaşlarına bakıldığında minimum olarak 14 yaş ile esrar kullanımı dikkati çekmektedir (Tablo 2).

Tablo2. Öğrencilerin ilk kez madde kullanım yaşları.

\begin{tabular}{|l|c|c|c|c|}
\hline Madde & $\mathbf{n}$ & $\begin{array}{c}\text { Minimum } \\
\text { yaş }\end{array}$ & $\begin{array}{c}\text { Maximum } \\
\text { yaş }\end{array}$ & Ortalama \\
\hline Esrar & 46 & 14 & 22 & 18,5 \\
\hline Eroin & 9 & 15 & 23 & 18,4 \\
\hline Kokain & 11 & 16 & 20 & 18,2 \\
\hline LSD & 6 & 17 & 23 & 19,5 \\
\hline Ecstasy & 9 & 16 & 21 & 18,4 \\
\hline Bonzai & 7 & 18 & 21 & 19,6 \\
\hline
\end{tabular}

Öğrencilerin madde kullanma nedeniniz neydi sorusuna $\% 86,8$ 'inin merak yanıtını verdiği görülmektedir (Tablo 3).

Tablo 1. Öğrencilerin madde kullanım nedenlerinin dağılımı.

\begin{tabular}{|l|c|}
\hline Merak & $\% 86,8$ \\
\hline Sorunlarını unutmak & $\% 24,5$ \\
\hline Psikolojik problemler & $\% 20,8$ \\
\hline Aile içi problemler & $\% 18,9$ \\
\hline Sosyal yaşantıda yer edinme & $\% 11,3$ \\
\hline Diğer & $\% 9,4$ \\
\hline
\end{tabular}

Hayatınızda hiç adı geçen maddeleri denemediyseniz nedeni neydi sorusuna \%64,0’ü sağlı̆̆ıma zararlı olacağını düşündüğüm için, \%59,2'si merak etmediğim için yanıtını vermiştir. \%14,2'si suç olduğunu bildiğim için, \%5,2'si ceza almaktan korktuğum için, \%3,8'i yakalanmaktan korktuğum için yanıtını vermiştir (Tablo 4).

Tablo 4. Öğrencilerin uyuşturucu madde denememe nedenlerinin dağılımı.

\begin{tabular}{|l|c|}
\hline Sağlığıma zararlı olacağını düşündüğüm için & $\% 64,0$ \\
\hline Merak etmediğim için & $\% 59,2$ \\
\hline İnançlarıma ters olduğu için & $\% 38,9$ \\
\hline Bağımlılık etkisinden korktuğum için & $\% 34,6$ \\
\hline Çevremde kullanan kimse olmadığı için & $\% 19,0$ \\
\hline Nedenini bilmiyorum ama denemedim & $\% 15,2$ \\
\hline Suç olduğunu bildiğim için & $\% 14,2$ \\
\hline $\begin{array}{l}\text { Aileme yakalanmaktan/mahcup olmaktan } \\
\text { korktuğum için }\end{array}$ & $\% 7,1$ \\
\hline Ceza almaktan korktuğum için & $\% 5,2$ \\
\hline Yakalanmaktan korktuğum için & $\% 3,8$ \\
\hline Diğer & $\% 0,5$ \\
\hline
\end{tabular}

Öğrencilerin \%60,2'si insanların bir ya da iki kez madde denemekle kendilerini riske attıklarını, \%90,2'si ise düzenli olarak madde kullanmakla riske attıklarını düşünmektedir. \%80,2'si toplumumuzda madde kullanım oranlarının her geçen yıl arttığını belirtmiştir (Tablo 5). 
Tablo 5. Öğrencilerin madde kullanımıyla ilgili bakış açıları.

\begin{tabular}{|l|c|c|c|}
\hline & Katılıyorum & Emin değilim & Katılmıyorum \\
\hline $\begin{array}{l}\text { İnsanlar bir ya da iki kez madde denemekle kendilerini fiziksel ya } \\
\text { da diğer yönlerden riske atmazlar }\end{array}$ & $\% 26,1$ & $\% 13,6$ & $\% 60,2$ \\
\hline $\begin{array}{l}\text { İnsanlar düzenli olarak madde kullanmakla kendilerini fiziksel ya } \\
\text { da diğer yönlerden riske atarlar }\end{array}$ & $\% 90,2$ & $\mathrm{t} 5,3$ & $\% 4,5$ \\
\hline Toplumumuzda madde kullanım oranları her geçen yıl artmaktadır & $\% 80,2$ & $\% 16,3$ & $\% 3,4$ \\
\hline İnsanların madde bulmaları kolaydır & $\% 67,2$ & $\% 29,1$ & $\% 3,8$ \\
\hline Ĕger isteseydim madde elde etmek benim için kolay olurdu & $\% 48,3$ & $\% 31,2$ & $\% 20,5$ \\
\hline $\begin{array}{l}\text { Öğrencilik döneminde madde kullanırken yakalanan bir kişinin } \\
\text { ilerde meslek yaşantısı etkilenir }\end{array}$ & $\% 71,1$ & $\% 19,8$ & $\% 9,1$ \\
\hline
\end{tabular}

Tablo 6. Madde kullanan ve kullanmayan öğrencilerin madde kullanımılla ilgili ifadelere katılma oranları.

\begin{tabular}{|l|c|c|}
\hline & Kullanan & Kullanmayan \\
\hline $\begin{array}{l}\text { İnsanlar bir ya da iki } \\
\text { kez madde denemekle } \\
\text { kendilerini fiziksel ya } \\
\text { da diğer yönlerden riske } \\
\text { atmazlar }\end{array}$ & $\% 74,5$ & $\% 14,6$ \\
\hline $\begin{array}{l}\text { İnsanlar düzenli olarak } \\
\text { madde kullanmakla } \\
\text { kendilerini fiziksel ya da } \\
\text { diğer yönlerden riske atarlar }\end{array}$ & $\% 76,5$ & $\% 93,5$ \\
\hline $\begin{array}{l}\text { Toplumumuzda madde } \\
\text { kullanım oranları her } \\
\text { geçen yıl artmaktadır }\end{array}$ & $\% 82,4$ & $\% 79,7$ \\
\hline $\begin{array}{l}\text { İnsanların madde } \\
\text { bulmaları kolaydır }\end{array}$ & $\% 68,6$ & $\% 66,8$ \\
\hline $\begin{array}{l}\text { Eğer isteseydim madde } \\
\text { elde etmek benim için } \\
\text { kolay olurdu }\end{array}$ & $\% 80,4$ & $\% 40,6$ \\
\hline $\begin{array}{l}\text { Öğrencilik döneminde } \\
\text { madde kullanırken } \\
\text { yakalanan bir kişinin ilerde } \\
\text { meslek yaşantısı etkilenir }\end{array}$ & $\% 51,0$ & $\% 75,9$ \\
\hline
\end{tabular}

Madde kullanan ve kullanmayan öğrenciler arasında karşılaştırılma yapıldığında madde kullanan öğrencilerin $\% 74,5$ 'i, madde kullanmayan öğrencilerin ise \%14,6's1 insanların bir ya da iki kez madde denemekle kendilerini riske atmadıklarını düşünmektedir. Madde kullanan öğrencilerin \%80,4'ü, madde kullanmayan öğrencilerin ise $\% 40,6$ 's1 "eğer isteseydim madde elde etmek benim için kolay olurdu" yanıtını vermektedir (Tablo 6).

Öğrencilerin \%41,4'ü okul idaresinin madde kullanan öğrencileri fark etme olasılığını düşük olduğu fikrini beyan etmiştir. Öğrencilerin \%70,6'sının okul idaresinin bir öğrencinin madde kullanımından haberdar olması halinde disiplin cezası verme olasıllı̆ının yüksek olduğunu, $\% 51,5$ 'i de vereceği cezanın okuldan uzaklaştırmak veya atmak olacağını düşünmektedir. Okul idaresinin bir öğrencinin madde kullanımından haberdar olması halinde cezayı 1 aydan kısa bir sürede verir mi sorusuna öğrencilerin \%59,7'si emin değilim yanıtını vermiştir (Tablo 7).

Madde kullanan öğrencilerin \%56,0's1 okul idaresinin fark etme olasılığını düşük bulurken, madde kullanmayan öğrencilerde bu oran \%37,9'dur. Madde kullanan öğrencilerin \%66,0'sı okul idaresinin haberdar olması halinde disiplin cezası verme olasılığını yüksek bulurken, madde kullanmayan öğrencilerde bu oran \% $71,7^{\prime}$ dir. Okul idare-

Tablo 7. Öğrencilerin madde kullanımıyla ilgili okul idaresine yönelik düşünceleri.

\begin{tabular}{|c|c|c|c|}
\hline & Katılıyorum & Emin değilim & Katılmıyorum \\
\hline Madde kullanan öğrencileri okul idaresinin fark etme olasıllğı düşüktür & $\% 41,4$ & $\% 27,2$ & $\% 31,4$ \\
\hline $\begin{array}{l}\text { Okul idaresinin bir öğrencinin madde kullanımından haberdar } \\
\text { olması halinde disiplin cezası verme olasılığı yüksektir }\end{array}$ & $\% 70,6$ & $\% 21,8$ & $\% 7,6$ \\
\hline $\begin{array}{l}\text { Okul idaresinin bir öğrencinin madde kullanımından haberdar } \\
\text { olması halinde vereceği ceza okuldan uzaklaştırmak veya atmak olur }\end{array}$ & $\% 51,5$ & $\% 37,9$ & $\% 10,6$ \\
\hline $\begin{array}{l}\text { Okul idaresinin bir öğrencinin madde kullanımından haberdar } \\
\text { olması halinde vereceği ceza uyarı ya da kınama olur }\end{array}$ & $\% 30,2$ & $\% 43,1$ & $\% 26,7$ \\
\hline $\begin{array}{l}\text { Okul idaresi bir ögrencinin madde kullanımından haberdar olması } \\
\text { halinde hiçbir ceza vermez }\end{array}$ & $\% 10,3$ & $\% 29,1$ & $\% 60,5$ \\
\hline $\begin{array}{l}\text { Okul idaresi bir öğrencinin madde kullanımından haberdar olması } \\
\text { halinde cezayı } 1 \text { aydan kısa bir sürede verir }\end{array}$ & $\% 27,8$ & $\% 59,7$ & $\% 12,5$ \\
\hline
\end{tabular}


sinin bir öğrencinin madde kullanımından haberdar olmas1 halinde hiçbir ceza vermeyeceğini düşünenlerin oranı madde kullananlarda $\% 9,8$, kullanmayanlarda $\% 10,5$ 'tir (Tablo 8).

Tablo 8. Madde kullanan ve kullanmayan öğrencilerin madde kullanımıyla ilgili okul idaresine yönelik ifadeler katılma oranları.

\begin{tabular}{|l|c|c|}
\hline & Kullanan & Kullanmayan \\
\hline $\begin{array}{l}\text { Madde kullanan } \\
\text { öğrencileri okul idaresinin } \\
\text { fark etme olasılığı } \\
\text { düşüktür }\end{array}$ & $\% 56,0$ & $\% 37,9$ \\
\hline $\begin{array}{l}\text { Okul idaresinin bir } \\
\text { öğrencinin madde } \\
\text { kullanımından haberdar } \\
\text { olması halinde disiplin } \\
\text { cezası verme olasılığ1 } \\
\text { yüksektir }\end{array}$ & $\% 66,0$ & \\
\hline $\begin{array}{l}\text { Okul idaresinin bir } \\
\text { öğrencinin madde } \\
\text { kullanımından haberdar } \\
\text { olması halinde } \\
\text { vereceği ceza okuldan } \\
\text { uzaklaştırmak veya atmak } \\
\text { olur }\end{array}$ & $\% 71,7$ \\
\hline $\begin{array}{l}\text { Okul idaresinin bir } \\
\text { öğrencinin madde } \\
\text { kullanımından haberdar } \\
\text { olması halinde vereceği } \\
\text { ceza uyarı ya da kınama } \\
\text { olur }\end{array}$ & $\% 27,5$ & $\% 10,5$ \\
\hline $\begin{array}{l}\text { Okul idaresi bir öğrencinin } \\
\text { madde kullanımından } \\
\text { haberdar olması halinde } \\
\text { hiçbir ceza vermez }\end{array}$ & $\% 30,8$ \\
\hline $\begin{array}{l}\text { Okul idaresi bir öğrencinin } \\
\text { madde kullanımından } \\
\text { haberdar olması halinde } \\
\text { cezayı 1 aydan kısa bir } \\
\text { sürede verir }\end{array}$ & $\% 9,1$ \\
\hline
\end{tabular}

Madde kullanan kişinin alacağı ceza sizce nedir sorusuna öğrencilerin $\% 41,3$ 'ü denetimli serbestlik, \%14,1'i hapis cezası, $\% 10,5$ 'i para cezası yanıtını vermiştir. Hiçbir ceza verilmez diyenlerin oran $1 \% 12,0$, fikrim yok diyenlerin oranı da $\% 29,0$ 'dır.

Öğrencilerin \%71,6'sının madde kullanımının yasal olarak suç olduğunu bildiği, \%44,2'sinin madde kullanımına verilen cezaların caydırıcı olmadığını düşündüğü görülmektedir. \%56,3'ü madde kullanımından dolayı bir kişinin adalet önüne çıkarılmasının kısa sürüp sürmediği konusunda emin olmadığını, \%55,0'i de cezalandırılmasının uzun sürüp sürmediği konusunda emin olmadığını belirtmiştir (Tablo 9).

Madde kullanan öğrencilerin \%70,6's1, madde kullanmayan öğrencilerin \% 71,8'i madde kullanımının yasal olarak suç olduğunu belirtmektedir. Madde kullanan öğrencilerin \%54,9'u, kullanmayan öğrencilerin ise \%24,1'i madde kullanımından dolayı bir kişinin yakalanma olasılığını düşük bulmaktadır. Madde kullanımına verilen cezaların caydırıcı olduğunu düşünenlerin oranı madde kullanan öğrencilerde \%21,6, madde kullanmayan öğrencilerde ise \%15,9'dur (Tablo 10).

\section{Tartışma}

Yapılan araştırmalara göre madde kullanımına yol açan en önemli etkenlerden birinin merak olduğu görülmektedir (17). Bizim çalışmamızda da öğrencilerin \%86,8'inin merak nedeniyle madde kullandığ 1 görülmüştür. Katılımcıların \%17,9 ile en yüksek oranda esrar kullandığı, ilk kez madde kullanım yaşlarına bakıldığında da minimum 14 yaş ile yine esrar kullanımı dikkati çekmektedir

Kelly ve ark.nın (2014) yaptığı araştırmaya göre kullanıcıların çoğu $(\% 59,1)$ metamfetamini bir ya da iki kez kullanmanın kullanıcı için risk teşkil etmediğini düşünmektedir. Bu düşünceler metamfetaminin düzenli kullan1$\mathrm{m}$ söz konusu olduğunda değişmektedir. Metamfetaminin haftada bir ya da iki kez kullanımının oluşturacağı riskler sorulduğunda katılımcıların yalnızca \%19,8'i hiçbir risk olmadığını belirtmiş, çoğunluğu ise $(\% 56,7)$ düzenli kul-

Tablo 9. Öğrencilerin madde kullanımıyla ilgili yasal süreçlere ilişkin düşünceleri.

\begin{tabular}{|l|c|c|c|}
\hline & Katılıyorum & $\begin{array}{c}\text { Emin } \\
\text { değilim }\end{array}$ & Katılmıyorum \\
\hline Madde kullanımı yasal olarak suçtur & $\% 71,6$ & $\% 16,7$ & $\% 11,7$ \\
\hline Madde kullanımından dolayı bir kişinin yakalanma olasılığı düşüktür & $\% 30,0$ & $\% 35,4$ & $\% 34,6$ \\
\hline Madde kullanımından dolayı bir kişinin adalet önüne çıarııııı kısa sürer & $\% 20,5$ & $\% 56,3$ & $\% 23,2$ \\
\hline Madde kullanımdan dolayı bir kişinin cezalandırılması uzun sürer & $\% 24,8$ & $\% 55,0$ & $\% 20,2$ \\
\hline Madde kullanımına verilen cezalar caydııııdır & $\% 17,0$ & $\% 38,9$ & $\% 44,2$ \\
\hline $\begin{array}{l}\text { Kolluk kuvvetlerinin (polis, jandarma) genel asayiş uygulamasında şüphelendiği } \\
\text { kişileri madde kullanım testine göndermesi caydırııı etki oluşturur }\end{array}$ & $\% 56,2$ & $\% 26,8$ & $\% 17,0$ \\
\hline $\begin{array}{l}\text { Yasal düzenleme yapılarak iş yeri ve okullarda rastgele madde testleri } \\
\text { uygulanması caydırıcı etki oluşturur }\end{array}$ & $\% 62,1$ & $\% 22,7$ & $\% 15,2$ \\
\hline
\end{tabular}


Tablo 10. Madde kullanan ve kullanmayan öğrencilerin madde kullanımıyla ilgili yasal süreçlere ilişkin ifadelere katılma oranları.

\begin{tabular}{|l|c|c|}
\hline $\begin{array}{l}\text { Madde kullanımı yasal olarak } \\
\text { suçtur }\end{array}$ & Kullanan & Kullanmayan \\
\hline $\begin{array}{l}\text { Madde kullanımından } \\
\text { dolayı bir kişinin yakalanma } \\
\text { olasılı̆̆ı düşütür }\end{array}$ & $\% 54,9$ & $\% 71,8$ \\
\hline $\begin{array}{l}\text { Madde kullanımından dolayı } \\
\text { bir kişinin adalet önüne } \\
\text { Çıarılması kısa sürer }\end{array}$ & $\% 25,5$ & $\% 19,3$ \\
\hline $\begin{array}{l}\text { Madde kullanımdan dolayı } \\
\text { bir kişinin cezalandırılması } \\
\text { uzun sürer }\end{array}$ & $\% 29,4$ & $\% 23,7$ \\
\hline $\begin{array}{l}\text { Madde kullanımına verilen } \\
\text { cezalar caydırıcıdır }\end{array}$ & $\% 21,6$ & $\% 15,9$ \\
\hline $\begin{array}{l}\text { Kolluk kuvvetlerinin (polis, } \\
\text { jandarma) genel asayiş } \\
\text { uygulamasında şüphelendiği } \\
\text { kişileri madde kullanım } \\
\text { testine göndermesi caydırıcı } \\
\text { etki oluşturur }\end{array}$ & $\% 52,9$ & $\% 57,0$ \\
\hline $\begin{array}{l}\text { Yasal düzenleme yapılarak } \\
\text { iş yeri ve okullarda rastgele } \\
\text { madde testleri uygulanması } \\
\text { caydırıcı etki oluşturur }\end{array}$ & $\% 58,8$ & $\% 62,9$ \\
\hline
\end{tabular}

lanımda en azından orta derecede risk olduğunu beyan etmiştir (1). Bizim çalışmamızda da benzer şekilde öğrencilerden insanların bir ya da iki kez madde denemekle kendilerini fiziksel ya da diğer yönlerden riske atmayacaklarını düşünenlerin oranı $\% 26,1$ iken, düzenli kullanım söz konusu olduğunda bu oran \%90,2'ye çıkmaktadır.

Cezaların caydırıcı olabilmeleri için Beccaria'nın (2003) ortaya koyduğu üç temel prensip olan [1] kesinlik (certainty), [2] hızlılık (celerity/swiftness) ve [3] şiddetlilik (severity) bağlamında sorulan sorulara bakıldığında ise şu şekilde sonuçlar elde edilmiştir:

1. Kesinlik prensibi bağlamında öğrenciler madde kullanımından dolayı kişinin yakalanma olasılı̆̆ının düşük olduğunu ve madde kullanımına verilen cezaların caydırıcı olmadığını düşünmektedir.

2. Hızlılık prensibi bağlamında öğrencilerin bu konuda tam net fikirlerinin olmadığı görülmektedir.

3. Şiddetlilik prensibi bağlamında ise öğrenciler madde kullanımına verilen cezaların caydırıcı olmadığını ifade etmişlerdir.

Buna göre çalışmamızda katılımcıların madde kullanımına verilen cezalar konusunda kesinlik ve şiddetlilik prensibine olan inançlarının düşük olduğu görülmüştür.
Öğrencilere aynı prensipler açısından okul idaresi ile ilgili sorulan soruların sonuçlarına bakıldığında ise;

1. Kesinlik prensibi bağlamında öğrenciler okul idaresinin madde kullanan öğrenciyi fark etme olasılığının düşük olduğunu düşünmekte fakat fark ettiği anda ceza verme olasıllğının yüksek olduğunu düşünmektedir.

2. Hızlılık prensibi bağlamında öğrencilerin okul idaresinin ceza verme süresiyle ilgili fikirlerini olmadığ görülmektedir.

3. Şiddetlilik prensibi bağlamında öğrenciler sırasıyla disiplin cezası, okuldan uzaklaştırma, atılma veya uyarı ya da kınama cezası alabileceklerini düşünmektedirler. Her iki sonuçlar birlikte değerlendirildiğinde ilk prensip olan kesinlik ilkesinin caydırıcı etkisinin olmadığ görülmektedir. Katılımcılar, madde kullanımından dolayı fark edilme ve yakalanma olasılığını düşük olarak görmektedirler.

Özcan ve ark.nın (2011) lise öğrencileri ile yaptığı araştırmada öğrencilerin \%37,1'i okul idaresi tarafindan uyuşturucu kullanımının fark edilmesi ve şikayet edilmesi ihtimalini yüksek bir olasılık olarak değerlendirmiştir. Bizim çalışmamızda ise bu oran \%31,4'tür. Okul idaresinin vereceği cezayı da öğrencilerin \%21,4'ü çok ağır bir ceza, $\% 46,1$ 'i ise ağır bir ceza olarak öngörmektedir. Bizim çalışmamızda da öğrencilerin \%70,6'sı disiplin cezası, $\% 51,5$ 'i de okuldan uzaklaştırılma veya atılma alabileceğini düşünmektedir. Yani diğer çalışmayla benzer şekilde okul idaresi tarafindan fark edilme halinde yüksek bir ceza alabileceklerine dair bir inançları vardır. Ancak; Okul idaresinin bir öğrencinin madde kullanımından haberdar olması halinde hiçbir ceza vermeyeceğini düşünenlerin oranı $\% 10,3$ 'tür ve bunun da azımsanmayacak bir oran olduğu düşünülmektedir. Uyuşturucu kullanımı yüzünden hapis cezası alma ihtimalleri sorulduğunda ankete katılanların bu soruya vermiş oldukları ortalama değer $4,8 / 10$ 'dir. Bizim araştırmamızda madde kullanan kişinin alacağı ceza sizce nedir sorusuna öğrencilerin \%41,3'ü denetimli serbestlik, \%14,1'i hapis cezası yanıtını vermiştir. Diğer çalışma lise öğrencileriyle yapılmış olduğu için onlara göre daha az oranda hapis cezası alabilecekleri görülmekle birlikte aslında gerek Özcan ve ark.nın (2011) araştırmasına benzer şekilde bizim araştırmamızda da öğrencilerin hapis cezası ile ilgili bilgilerinin olmadığı görülmektedir.

18 Ağustos 2012 tarihli 28388 sayılı Resmî Gazete'de yayımlanmış olan Yükseköğretim Kurumları Öğrenci Disiplin Yönetmeliği’nin 8. Maddesinin 1. fikrası (ç) bendinde "Yükseköğretim kurumları içerisinde uyuşturucu ve uyarıcı madde kullanmak, taşımak, bulundurmak, Yükseköğretim kurumundan iki yarıyıl için uzaklaştırma cezasını gerektiren disiplin suçları" olarak tanımlanmaktadır. 22. Maddesinin 2. fikrasinda "Disiplin kurulu, dos- 
yayı aldığı tarihten itibaren en geç on gün içinde karar vermek zorundadır" şeklinde belirtilmektedir (18). Bizim çalışmamızda buna yönelik "Okul idaresinin bir öğrencinin madde kullanımından haberdar olması halinde vereceği ceza okuldan uzaklaştırmak veya atmak olur" diyen öğrencilerin oranının \%51,5 olduğu görülmektedir. Buna göre öğrencilerin Yükseköğretim Kurumları Öğrenci Disiplin Yönetmeliği ile ilgili fazla bilgi sahibi olmadıklarını söylemek mümkündür.

Öğrencilere anket çalışmasında madde kullanmama nedenleri sorulduğunda \%64'ünün sağlığıma zararlı olacağını düşündüğüm için yanıtı verdiği görülmüştür. Yakalanma risk algısına bağlı olarak ceza almaktan ve yakalanmaktan korktuğum için yanıtını verenlerin oranının ise toplamda $\% 9$ olduğu görülmüştür.

$\mathrm{Bu}$ bağlamda öğrencilerin madde kullanımına verilen cezalar ile ilgili net bir bilgi sahibi olmadıkları ve cezai yaptırımlar konusunda özellikle kesinlik ve şiddetlilik prensiplerine olan inançlarının düşük olduğunu söylemek mümkündür.

\section{Sonuç}

Suçla mücadelede en önemli unsurlardan biri ceza politikalarıdır. Günümüzde suç ve suçlulukla etkin bir şekilde mücadele edebilmek için cezaların caydırıcı ve ıslah edici olması büyük önem taşır. Yakalanma ve cezalandırılma risk algısı, suç işleme eğilimi içinde olan bireylerde caydırıcı bir etki taşımaktadır. Ancak bunun caydırıcılığının daha etkin olabilmesi için bireylerin cezai yaptırımlar konusunda caydırıcılık prensipleri olan kesinlik, hızlılık ve şiddetlilik prensiplerinin etkin olduğuna dair inançlarının yüksek olması gerekmektedir. Yani bireyler yakalanacağı ve ceza alacağ 1 konusunda yüksek bir inanca sahip olurlarsa suç işlemekten cayacaklardır. Ancak suçla mücadelede sadece cezaların arttırılması tek başına bir çözüm olarak görülmemelidir. Son yıllarda madde kullanım yaygınlığının arttığı göz önüne alındığında bu sorunu sadece birey bazlı değil toplum bazlı olarak düşünmek gerekmektedir.

$\mathrm{Bu}$ doğrultuda; madde kullanımında caydırıcılık etkisine daha geniş örneklemlerde bakılmasının daha aydınlatıcı bilgiler verebileceği düşünülmektedir.

Ayrıca; madde kullanımı konusunda özellikle ailelerin ve gençlerin eğitilmesi, bilgilendirilmesi; madde kullanımıyla ilişkili cezai yaptırımlar konusunda bireylere farkındalık kazandırılması; ceza adalet sistemi içerisinde soruşturma ve kovuşturma işlemlerinin daha etkin ve hız11 sağlanmasının büyük önem taşıdığı düşünülmektedir.

\section{Kaynaklar}

1. Dolu, O. Suç Teorileri: Teori, Araştırma ve Uygulamada Kriminoloji. Global Politika ve Strateji Yayınları, 2015: 5. Bask1, Ankara.
2. Einstadter, W. \& Henry, S. Criminological Theory: An Analysis of Its Underlying Assumptions, Forth Worth, TX: 1995; Harcourt Brace College Publishers.

3. İçli, T. G. ve Öğün A. (1999). Türkiye'de Cezaevlerindeki Rehabilitasyon Faaliyetleriyle İlgili Sosyolojik Bir Analiz, Ankara:1999; Ankara Açık Cezaevi Yayınları.

4. Livingston, J. Crime and Criminology, USA: 1996; Prentice Hall.

5. Beccaria, Cesare. "An Essay on Crimes and Punishments.” In Francis T. Cullen and Robert Agnew (eds), Criminological Theory: Past to Present - Essential Readings, Second Edition,2003; pp.20-22.

6. Sherman, L. W. "Defiance, Deterrence, and Irrelevance: A Theory of the Criminal Sanction", Journal of Research in Crime and Delinquency, 1993; Vol.30, No.4, pp. 445-473.

7. Bachman J.G., Johnston L.D. and O'Malley P.M. Explaining the Recent Decline in Cocaine Use among Young Adults: Further Evidence That Perceived Risks and Disapproval Lead to Reduced Drug Use Journal of Health and Social Behavior 1990; Vol. 31, No. 2, pp. 173-184 DOI: https://doi.org/10.2307/2137171.

8. Johnson D. Forensic evidence preservation the emergency nurses' role. Aust Emerg Nurs J;1997;1: 37-40. DOI: https://doi. org/10.1016/S1328-2743(97)800326.

9. Kelly, B.C. (2005). Conceptions of risk in the lives of club drug using youth. Substance Use \& Misuse, 40: 1443 - 1459. DOI: https://doi.org/10.1081/JA-200066812.

10. Van Ree JM, Gerrits M, Vanderschuren L, Opioids, Reward and Addiction: An Encounter of Biology, Psychology, and Medicine, The American Society for Pharmacology and Experimental Therapeutics, 1999; 51 (2) 341-396.

11. Kelly, B.C., Liu, T., Zhang, G., Hao, W. \& Wang, J. Factors related to psychosocial barriers to drug treatment among Chinese methamphetamine users. Addictive Behaviors, 2014; 39, 1265 - 1271. DOI: https://doi.org/10.1016/j.addbeh.2014.04.012.

12. Özcan Y., Dolu, O. ve Gül S.K. Ceza Algısının Uyuşturucu Kullanımı Üzerindeki Caydırıcı Etkisi: Bursa İli Ortaöğretim Kurumlarında Bir Alana Araştırması. Polis Bilimleri Dergisi, 2011; 13 (4): 1-26.

13. World Health Organization - Dünya Sağlık Örgütü. Lexicon of Alcohol and Drug Terms Published by the World Health Organization. http://www.who.int/substance_abuse/terminology/ who_lexicon/en/ (Erişim Tarihi: 18.05.2015)

14. Ögel K. Madde kullanım bozuklukları epidemiyolojisi. Türkiye Klinikleri J İnt Med Sci; 2005;1:61-64.

15. Turhan E, İnandı T, Özer C, Akoğlu S. Üniversite öğrencilerinde madde kullanımı, şiddet ve bazı psikolojik özellikler. Türkiye Halk Sağlığ1 Dergisi; 2011;9: 33-44.

16. Madde Bağımlılığı ile Mücadele. Avrasya Üniversitesi Bağıml1lıkla Mücadele Merkezi. Slayt Sunumu. 25 s. [Son Erişim Tarihi: 22.05.2017] URL: https://www.avrasya.edu.tr/wp-content/ uploads/sites/80/2016/02/Madde-Bağımlılığ1-ile-Mücadele.pdf

17. Albayrak S. ve Balcı, S. Gençlerde Madde Bağımlılı̆̆ ve Önlenmesi. Hemşirelikte Eğitim ve Araştırma Dergisi. 2014; 11(2): $30-37$.

18. Yükseköğretim Kurumları Öğrenci Disiplin Yönetmeliği http://www.yok.gov.tr/web/guest/icerik//journal_content/56_ INSTANCE_rEHF8BIsfYRx/10279/17960 (Erişim Tarihi: 22.05.2017) 